\title{
Targeted Activation of T Cells with IL-2-Coupled Nanoparticles
}

\author{
Verena K. Raker ${ }^{1}$, Christian Becker ${ }^{1}{ }^{(}$, Katharina Landfester ${ }^{2}$ and Kerstin Steinbrink ${ }^{3, *}$ \\ 1 Department of Dermatology, Johannes Gutenberg-University Mainz, 55122 Mainz, Germany; \\ rakerv@uni-mainz.de (V.K.R.); christian.becker@unimedizin-mainz.de (C.B.) \\ 2 Max Planck Institute for Polymer Research, 55128 Mainz, Germany; landfest@mpip-mainz.mpg.de \\ 3 Department of Dermatology, Westfälische Wilhelms-University Münster, 48149 Münster, Germany \\ * Correspondence: kerstin.steinbrink@ukmuenster.de; Tel.: +49-(0)251/83-56504
}

Received: 29 July 2020; Accepted: 8 September 2020; Published: 9 September 2020

\begin{abstract}
Interleukin-2 (IL-2) is a T cell growth factor particularly required in regulatory $\mathrm{T}$ cell maintenance and memory $\mathrm{T}$ cell responses. High-dose IL-2 treatment was the first FDA-approved immunotherapy for cancer, while low-dose IL-2 administration has shown promise in allograft rejection and autoimmune and inflammatory diseases. However, its pleiotropic nature and the existence of IL-2 receptors with different binding affinity limit its therapeutic application. For an improved clinical applicability of the cytokine, a targeted receptor assignment must, therefore, be achieved. Nanoparticles allow controlling the location and dose of immunomodulating compounds and to specifically address specific receptors through targeted drug binding. In this review article we discuss the IL-2 biology and current clinical application with regard to nanoparticle-based IL-2-mediated manipulation of $\mathrm{T}$ cell responses in autoimmunity, chronic inflammation, and cancer.
\end{abstract}

Keywords: interleukin-2; nanoparticles; immunotherapy

\section{Introduction}

The use of nanoparticles for the administration of immunotherapeutics is advantageous compared to the use of free drugs, as all parameters of the effect (site of action, release, whereabouts) can be precisely controlled. Nanoparticles can, for example, protect their cargo from the surrounding biological milieu, extend its half-life, minimize its systemic toxicity, and control its delivery to defined immune or tumor cells. Due to these possibilities, nanoparticles will become an effective treatment option for allergic and autoimmune diseases as well as for cancer therapy [1-4]. Interleukin-2 (IL-2) is a T-cell growth factor, which became one of the first FDA-approved immunotherapeutic agents for the treatment of metastatic melanoma and renal cell cancer [5,6]. While its use in cancer therapy was high-dose, it was subsequently recognized that low doses of IL-2 preferentially expand tolerance-inducing regulatory T cells. Due to this effect, IL-2 is now successfully used in low doses to suppress graft rejection, autoimmune reactions, and chronic inflammation $[7,8]$. The context and dose-dependent different effects of IL-2 are based on the different distribution of differently affine monomeric, dimeric, and trimeric IL-2 receptors within the immune system [9]. While naïve CD8 ${ }^{+}$ $\mathrm{T}$ cells, $\mathrm{CD}^{+} / \mathrm{CD}^{+}$memory $\mathrm{T}$ cells, and $\mathrm{NK}(\mathrm{T})$ cells express the dimeric receptor with low affinity, regulatory $\mathrm{T}$ cells constitutively express the trimeric IL-2R with high affinity. In order to control the effect of therapeutically administered IL-2, attempts are being made to target it to low- or high-affinity receptors and to extend its half-life. Nanoparticle-based approaches combine these strategies and at the same time offer new possibilities to make IL-2 therapeutically more useful. 


\section{IL-2 and Its Initial Use in Cancer Therapy}

IL-2 is the second identified immune cell growth and differentiation factor (cytokine) and the first that has been cloned and recombinantly produced [10,11]. Due to its originally described effect as an autocrine survival and proliferation signal for $\mathrm{T}$ cells and the indispensable role of $\mathrm{T}$ cells in anti-tumor immunity [12], IL-2 was explored in cancer therapy early after its discovery [13]. Based on its dose-dependent effect on T cell proliferation and notably short half-life ( $<30 \mathrm{~min})$ in circulation [14], IL-2 was first administered in escalating doses of up to 120 million IU (MIU) in bolus infusions every eight hours. The maximum tolerated dose (126-150 MIU per day) achieved permanent tumor responses in a small subgroup of patients with melanoma and renal cell carcinoma [15], but was accompanied by massive cytokine release, inflammatory reaction, and vascular leak syndrome consisting of increased loss of intravascular fluid into extravascular spaces caused by interaction of IL-2 with IL-2 receptors on endothelial cells [16], reducing cell adhesion of the endothelia to each other or to the extracellular matrix [17]. Attempts to avoid the side effects by reducing the dose (to $72,000 \mathrm{U} / \mathrm{kg}$ ) resulted in a loss of effect on tumor growth [18]. Despite its low safety profile, IL-2 became an FDA-approved drug (Proleukin, Novartis; generic name Aldesleukin) for renal cell carcinoma and metastatic melanoma treatment.

\subsection{Producing and Responding Cells}

Cell-specific IL-2 knockouts and a fluorescent reporter mouse strain revealed that $\mathrm{T}$ cells are the main IL-2 source, although B cells and dendritic cells (DCs) contribute in select organs [19-22]. In T cells, IL-2 is rapidly and transiently produced upon engaging the T cell receptor (TCR) and costimulation by molecules such as CD28 on naive T cells. The transient nature of IL-2 secretion depends on transcriptional induction by TCR signals and stabilization of IL-2 mRNA by costimulatory signals, followed by transcriptional silencing of the IL-2 gene and rapid degradation of IL-2 mRNA [23]. One of the two IL-2 genes is randomly selected and transcribed first during T-cell activation, although IL-2 expression can become bi-allelic. However, since IL-2 transcripts are rapidly degraded IL-2 production appears monoallelic [22].

While the reasons for occasional remissions in IL-2-treated cancer patients remained unclear, further investigations continued to clarify its mode of action. Three different IL-2 receptor chains termed alpha (CD25), beta (CD122), and gamma (CD132, also known as the common cytokine receptor $\gamma$ chain) could be identified (Figure 1) [24]. CD25 binds IL-2 with low affinity ( $\mathrm{K}_{\mathrm{d}} \sim 10^{-8} \mathrm{M}$ ), CD122 and CD132 form a receptor of intermediate affinity $\left(\mathrm{K}_{\mathrm{d}} \sim 10^{-9} \mathrm{M}\right)$ and the combination of all three receptor chains generates an IL-2 receptor with high affinity $\left(\mathrm{K}_{\mathrm{d}} \sim 10^{-11} \mathrm{M}\right)$. CD122 and CD132 contain larger cytoplasmic domains whose heterodimerization is required for IL-2 signaling. In contrast, CD25 contains only a very short cytoplasmic domain and probably serves mainly to regulate the receptor affinity for IL-2. However, activated T cells also appear to secrete a soluble form of CD25 (sCD25) with currently unclear significance.

IL-2 binding to its receptors initiates signal transduction for the transcription of target genes through multiple signaling pathways. These include the Janus kinase (JAK) signal transducer and activator of transcription (STAT) pathway, the phosphoinositide 3-kinase (PI3K) Akt pathway, and the mitogen-activated protein kinase (MAPK) pathway (Figure 1) [25]. All of these three major pathways mediate the effect of IL-2 on cell proliferation, activation, differentiation, survival, and cytokine production in the immune cells. IL-2 presented bound to cellular IL-2R could also act in trans [26]. However, it should be noted that the affinity with which IL-2 can bind to IL-2R is relatively low with rapid on and off rates.

Contrary to the postulated role of IL-2 as a general T cell growth factor, knockout mice lacking the IL-2 gene as well as mice lacking CD122 or CD25 receptor chains did not show immunodeficiency but autoimmunity [27-29]. Subsequently, it was discovered that a small population of regulatory $\mathrm{T}$ cells (Treg), which is of central importance for the maintenance of peripheral immune tolerance, constitutively expresses CD25 and high affinity IL-2 receptors and is unable to produce IL-2 [30,31]. 
Further studies revealed that IL-2 acts as a key Treg survival and maintenance factor, in part through epigenetic changes in the transcription factor FOXP3 gene, which determines their function [32]. The importance of IL-2 in maintaining Treg was further confirmed by their absence in IL-2 deficiency and by the fact that adoptively transferred Treg suppresses the development of autoimmunity in CD122-deficient mice [33]. One common observation of studies in IL-2 ${ }^{-/}, \mathrm{CD} 25^{-/-}$, or CD122 $2^{-/}$mice is that there is substantial $\mathrm{T}$ cell proliferation $[25,34,35]$. The conclusion from these observations is that IL-2 is less necessary for the development of effector T cells than for the maintenance of Treg, indispensable for immune tolerance and homeostasis.

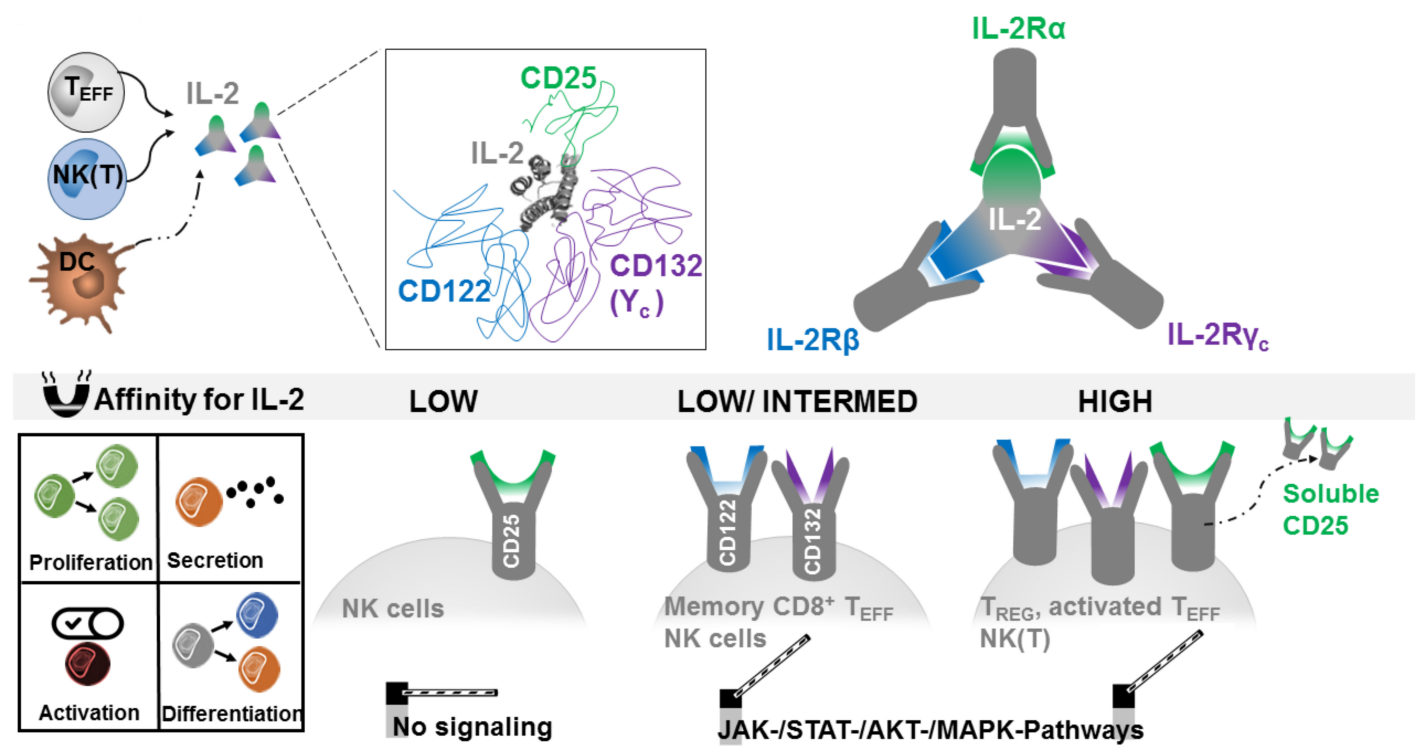

Figure 1. Interleukin-2 (IL-2) production, epitopes, and receptors. Interleukin-2 produced by T effector cells $\left(\mathrm{T}_{\mathrm{EFF}}\right)$, natural killer $(\mathrm{T})$ cells $(\mathrm{NK}(\mathrm{T})$ ), and dendritic cells (DC) binds to IL-2 receptors (IL-2Rs) CD25, CD122, and CD132. CD25 can be cleaved from the surface as a soluble form. Coexpression of CD122 and CD132 found on CD8 memory T cells has a low to intermediate IL-2 affinity, whereas the expression of all three receptors on activated $\mathrm{T}$ cells as well as regulatory $\mathrm{T}$ cells has high IL-2 affinity. IL-2-signaling pathways utilize different transcription factors and lead to proliferation, secretion of cytokines, activation, and differentiation of $\mathrm{T}$ cells.

The effects of IL-2 can be explained by the distribution of its receptors (Figure 2): At steady state high-affinity IL-2 receptors are preferentially expressed on Treg, while their expression is induced by activation on other immune cells. These include, in particular, T cells, NK cells, and NK T cells, which are also the primary IL-2 source besides dendritic cells [36]. At low IL-2 levels, this receptor distribution prefers Treg, while at high concentrations the cytokine also regulates cells with low affinity receptors, such as NK cells [37]. Improved knowledge about IL-2 and IL-2 receptors led to clinical studies investigating the possibility to therapeutically increase Treg numbers in autoimmune and inflammatory patients by low amounts of IL-2 [38,39]. Studies with low-dose IL-2 used different doses (in the range of 0.33 and 3 MIU per day) and different timelines. However, robust-dose and time-dependent Treg expansion was achieved in all studies and at all doses [40,41]. Depending on the treated disease and its course, adapted regimens have been developed that use mostly symptom-free phases to propagate Treg. Remarkably, in all low-dose IL-2 studies in autoimmune diseases, the expansion of Treg does not lead to generalized immunosuppression but restores immunoregulatory mechanisms [7]. Moreover, in contrast to high doses, low doses of IL-2 are well tolerated [38,42]. 


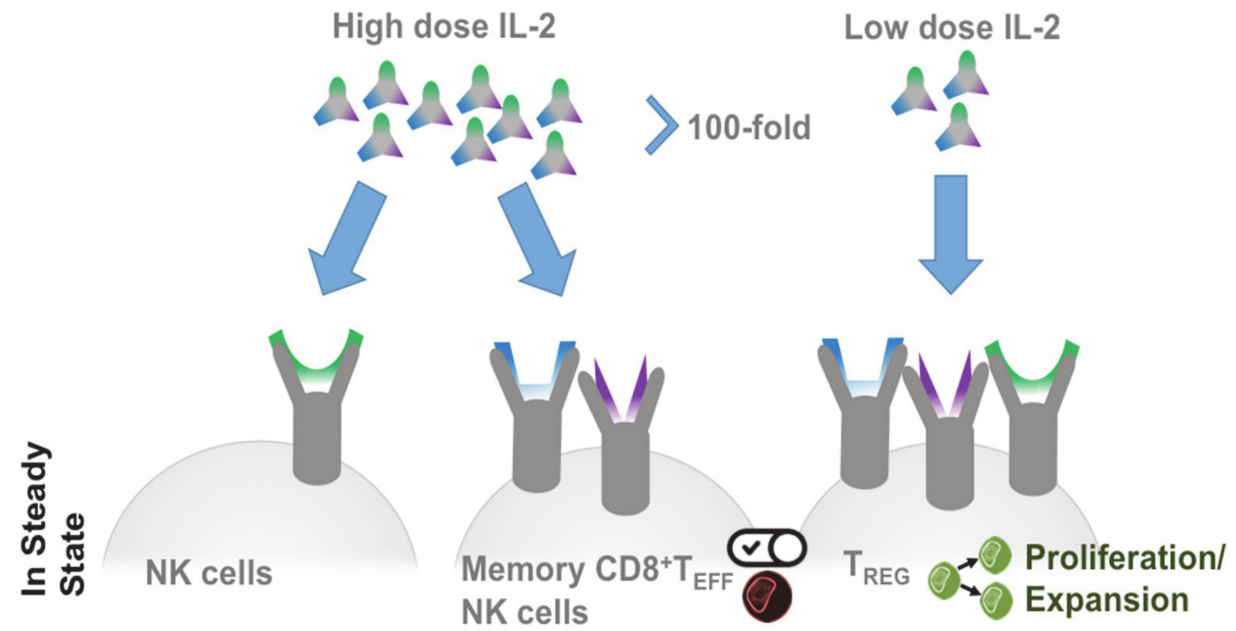

Figure 2. IL-2 dose-dependent receptor response. In steady state low to intermediate receptors respond to high doses of IL-2. A 100-fold reduction of the IL-2 dose targets regulatory T cells through their high affinity IL-2 receptor and leads to selective proliferation and expansion of regulatory T cells (Treg).

\subsection{Treg in Cancer}

Increased Treg frequencies in tumor tissue are associated with a poor prognosis in a large number of tumors [43-45] and, experimentally, immune responses to transplanted tumors improve after selective Treg removal [46-48]. These observations have led to the widespread idea that Treg helps the tumor to escape an efficient antitumor immune response [49]. However, there are also observations to the contrary: Increased Treg cell counts in colon and breast cancer correlate with a better clinical outcome [50-52] and the experimental removal of Treg is only effective early after tumor inoculation [46]. Most likely, Treg suppress inflammation-dependent cancer, as well as the inflammation-dependent implantation of tumor cells, but promote non-inflammatory tumors by suppressing the inflammatory pathways necessary for their successful control.

\subsection{Targeted IL-2 Assignment}

In order to be able to control the effect of therapeutically administered IL-2, attempts were being made to modify IL-2 so that it specifically binds low-affinity or high-affinity receptors. Using specific antibody clones, Jonathan Sprent and others showed that the blockage of individual IL-2 epitopes by antibodies has potential to target interaction of IL-2 to particular subtypes of receptors and, thus, cell types (Figure 3) $[16,53,54]$. This strategy, initially tested in mice, was being continued for human IL-2 [55]. Mutated forms of IL-2 were produced and clinically tested with the same goal, inter alia, by improving the binding to CD122 [56-58]. In addition, orthogonal IL-2 cytokine receptor pairs have been developed that interact with each other, but not with their natural cytokine and receptor counterparts, and show good efficacy in the mouse model [59]. While cytokine-antibody complexes can be much more effective than unmodified cytokines [54], the antibodies used must be humanized for clinical use.

An important disadvantage of natural IL-2 consists of its short life span. Here, the conjugation of therapeutic agents to polymeric carriers, such as polyethylene glycol (PEG), offers the advantage of improved drug solubilization and prolonged circulation [60]. Recently, PEGylated interleukin-2 (Bempegaldesleukin) has been shown to provide superior anti-tumor activity over native IL-2 and systemically expands anti-tumor $\mathrm{CD} 8^{+} \mathrm{T}$ cells while inducing Treg depletion in tumor tissue [61]. An extension of the half-life can also be achieved by using fusion proteins consisting of IL-2 and the crystallizable region $(\mathrm{Fc})$ of the antibody fragment. The use of a mutated IL-2 that is not bound to CD25 results in long-lived IL-2-Fc variants in which the undesired Treg activation is avoided. 
Surprisingly, however, such variants are less effective than wild-type IL-2-Fc in mediating tumor rejection, since Fc-mediated immune effector functions appear to be required for Treg elimination [62].

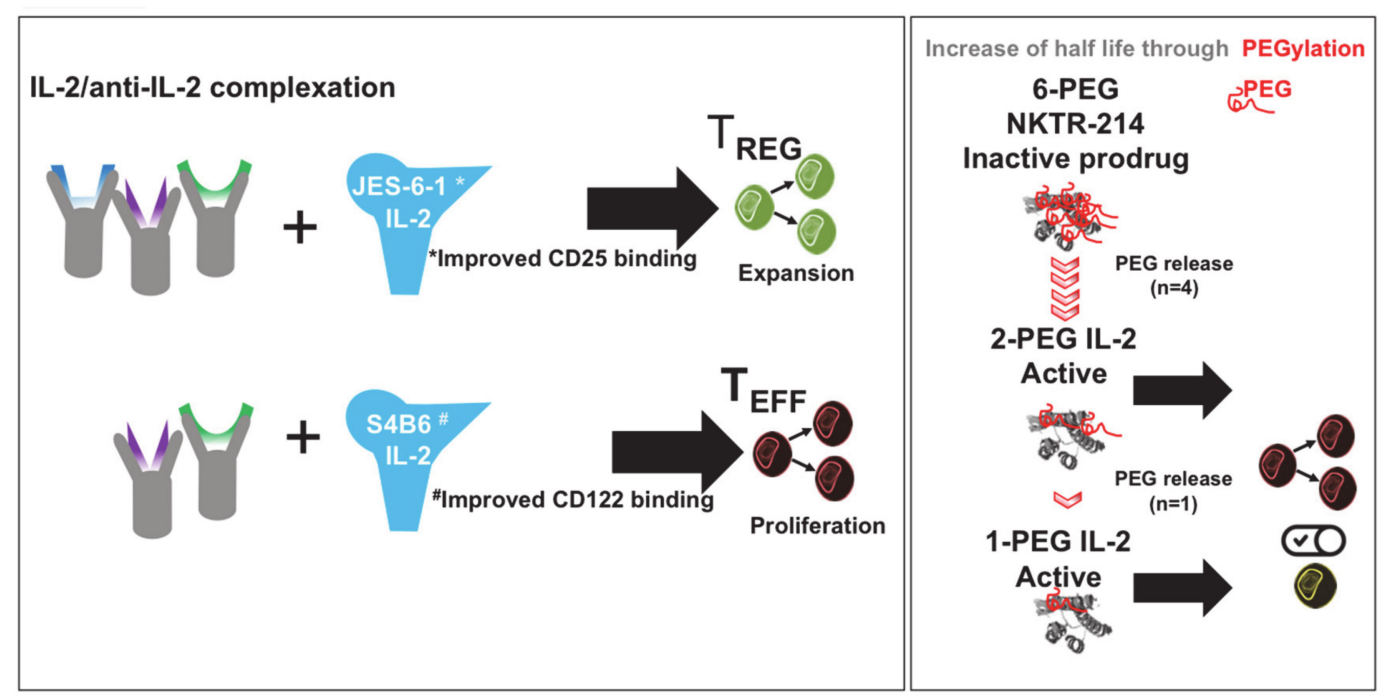

Figure 3. IL-2 modification for cellular targeting and prolonged half-life. IL-2 complexation with monoclonal antibodies (named JES-6-1 and S4B6) improves binding to either CD25 (JES-6-1/IL-2 complex) or CD122 (S4B6/IL-2 complex). This allows researchers to expand Treg numbers by JES-6-1/IL-2 complexes and increase proliferation of effector T cells by S4B6/IL-2 complexes. PEGylation of IL-2 forms 6-PEG IL-2, which is inactive and upon release of 4 PEG becomes activated. Further release of 1 PEG increases the half-life of active 1-PEG IL-2 in the circulation.

\subsection{IL-2-Decorated Nanoparticles to Boost Melanoma Immunity-Potential Advantages and Pitfalls}

The production of IL-2 decorated particles for cancer therapy must follow the principles described here. Thus, the binding of IL-2 should be bound to the particles in such a way that preferential signaling via low-affinity IL-2 receptors is ensured. Alternatively, mutated IL-2 can be used that cannot bind to the high-affinity receptor. It is also conceivable to use antibodies (such as clone TCB1-3) against human IL-2 for particle- coupling that disfavors Treg stimulation [63].

The particles themselves must be stable, i.e., not subject to immediate disintegration or degradation, and must allow for extensive body distribution. Ideally, they should circulate in the blood and lymph for prolonged time and not accumulate locally. This means that they should be of a size and charge that is ignored by the mononuclear phagocytic (MPS) system [64] and made of a material that shows no accumulation in the liver [65]. Permanent, preferably covalent, binding must prevent IL-2 detachment in order to exclude uncontrolled effects (e.g., on Treg), which would otherwise lose the advantage of directional binding.

In principle, adjuvant stimulation of the immune system of cancer patients is associated with the risk of promoting autoimmunity [66,67]. Similarly, the effect and side effects of checkpoint inhibitors [68] show that anti-tumor immunity may not be achieved without this risk. Due to the similarity of tumor cells to their origin, effective tumor rejection by the immune system must even be understood as a local autoimmune reaction [69].

\subsection{T Cell Activation through Delivery of Nanoparticle-Encapsulated IL-2}

A number of studies have investigated the effect of nanocarrier-encapsulated IL-2 on the immune system (Figure 4). For this purpose, IL-2 was loaded into liposomes [70], poly(milk-co-glycolic) (PGLA) particles [71,72], poly n-(2-hydroxypropyl)methacrylamide (HPMA) particles [73], Chitosan nanoparticles [74], or bundled carbon nanotubes [75]. In some of the studies, the nanocarriers were combined with other substances, including doxorubicin [74], TGF- $\alpha$ [71], a TGF- $\alpha$ inhibitor [70], 
or peptide-MHC complexes [76]. The aim of these investigations was mainly to improve immune responses against tumors by IL-2-induced activation of tumor-infiltrating T cells. In this context, Fadel et al. additionally attached antigens to bundled carbon nanotubes and combined this complex with polymer nanoparticles containing magnetite and IL-2. By using these complexes, a thousand times less IL-2 was required for T-cell activation and expansion compared to soluble IL-2, and a delay in tumor growth was achieved in a melanoma model.

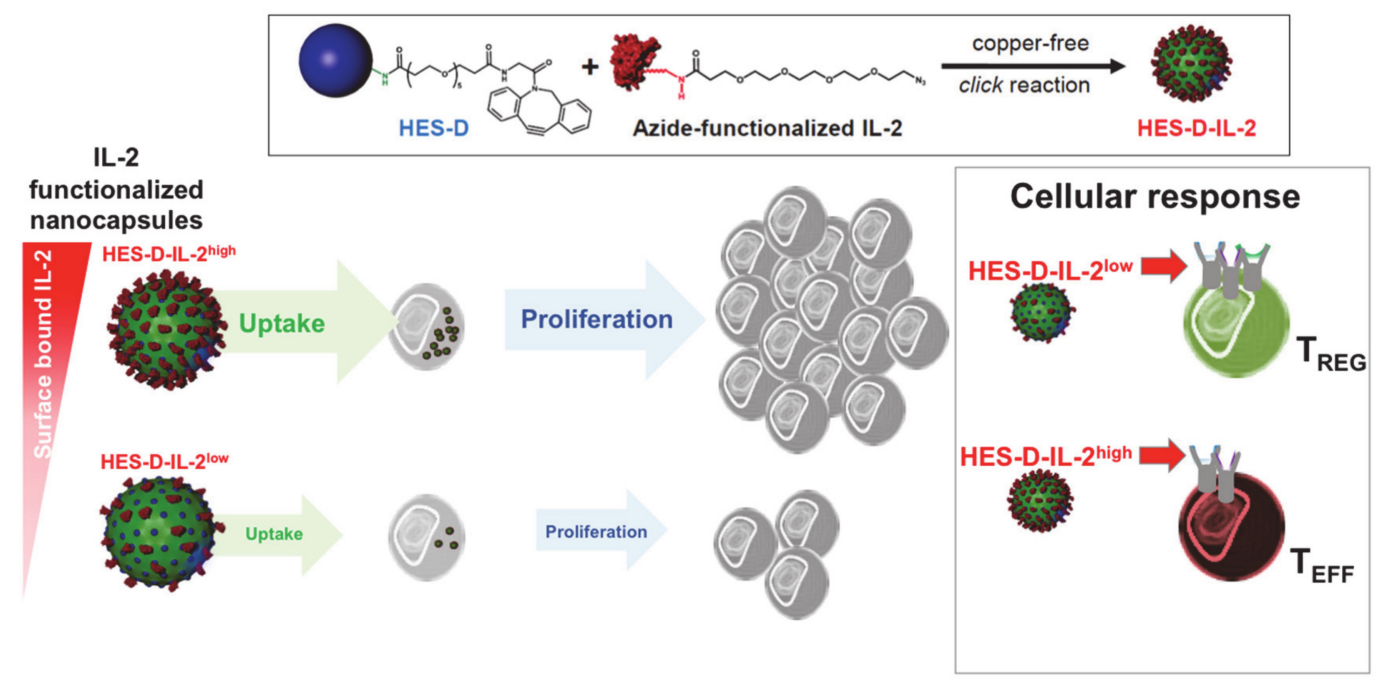

Figure 4. Bio-inspired nanoparticle-mediated IL-2 delivery strategies. Particle encapsulated IL-2 ensures a controlled release of the cytokine for treatment. Antibody-complexed IL-2 and dosed and oriented IL-2-coated particles enable receptor-specific targeting and activation.

As described above, $\mathrm{FOXP3}^{+}$Treg displays a pivotal role in the control of autoimmune and inflammatory diseases and low dose of IL-2 has been shown to stimulate regulatory $\mathrm{T}$ cells and enhance their suppressive capacity $[7,8]$. Therefore, several studies have focused on nanocarrier-based IL-2 application to modulate regulatory $\mathrm{T}$ cell biology and to affect autoimmune phenomena. For this purpose, in an experimental setting, Horwitz et al. loaded PLGA nanoparticles with IL-2 and TGF- $\beta$ and additionally coated them with anti-CD2/anti-CD4 antibodies to achieve T cell-specific targeting [71]. These nanoparticles induced an expansion of regulatory $\mathrm{T}$ cell in vitro and in vivo, and their systemic administration resulted in reduced disease activity in vivo in a murine model of Lupus erythematosus.

\subsection{T Cell Targeting by IL-2-Functionalized Nanoparticles}

Alternatively to its release from particles, IL-2 can be used as a surface molecule on nanoparticles for direct stimulation (Figure 4). Wojta-Stremayr et al. generated antigen-presenting virus-like nanoparticles (VPN) that co-express IL-2 bound to different membrane anchors. They found that the fusion of the C-terminus of IL-2 with a minimal glycosylphosphtidylinositol anchor acceptor sequence with two intervening immunoglobulin-like domains of CD16b led to an optimal stimulation of $\mathrm{T}$ cells and induction of $\mathrm{CD} 8^{+} \mathrm{T}$ cell effector function in vivo [77]. Other studies reported the generation of IL-2 surface conjugates on PEGylated liposomes using covalently bonded succinimidyl-4-p-maleimidophenyl butyrate-modified IL-2 or an Fc scaffold fused to the C-terminus of the murine IL-2 $[78,79]$. Using an adoptive cell therapy model, Zheng et al. found that the vast majority of antigen-specific $\mathrm{T}$ cells reacted to IL-2-decorated liposomes in vivo after a single injection and that repeated administrations increased cytotoxic $\mathrm{T}$ cell activation and proliferation in melanoma-bearing mice. We functionalized nanocapsules with different amounts of IL-2 and studied how they interact with different T-cell populations (Figure 5) [80]. 


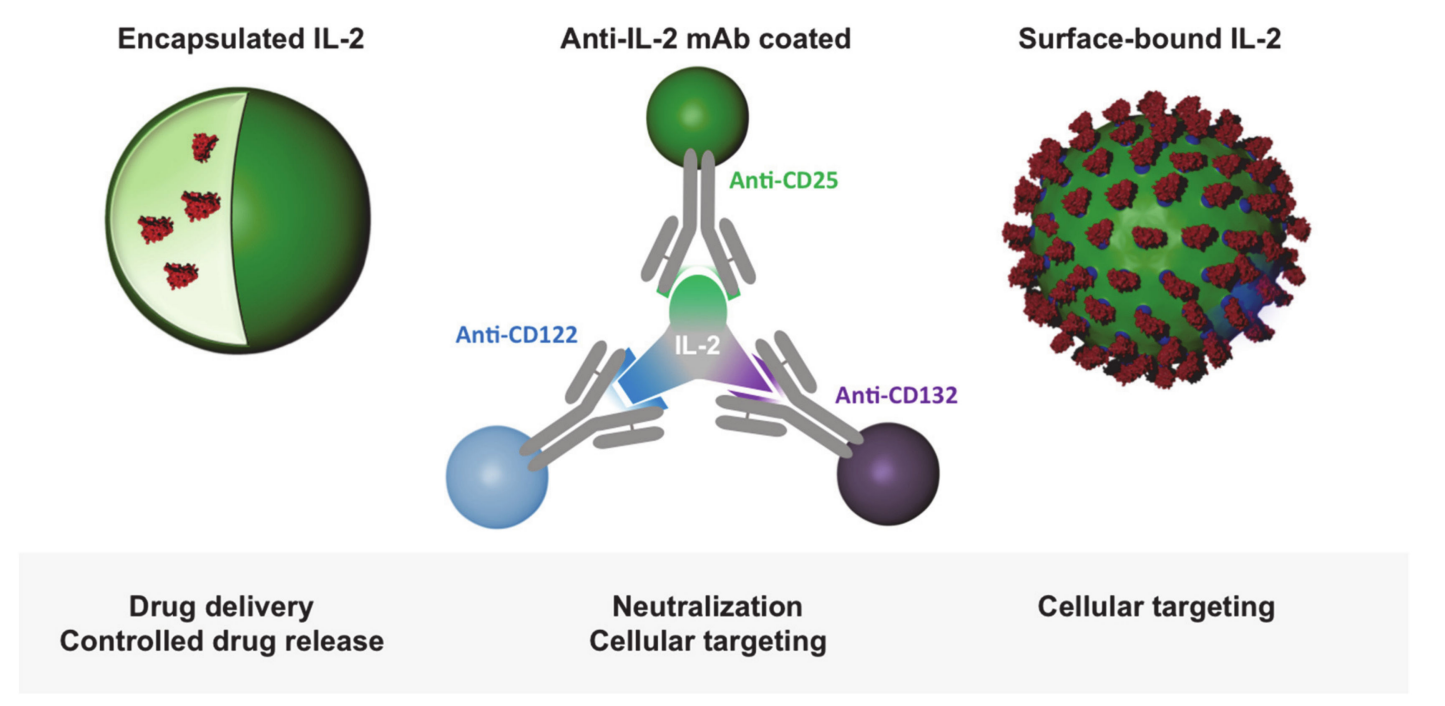

Figure 5. IL-2-functionalized nanocapsules for $\mathrm{T}$ cell targeting. Hydroxyethyl-starch (HES) nanocapsules were functionalized with dibenzylcyclooctyne (DBCO)-PEG 5 -NHS ester binding to $\mathrm{NH}_{2}$ groups on the carriers' surface to introduce an active alkyne group (HES-D). IL-2 was azide-functionalized at its $\mathrm{N}$ terminus and coupled onto the DBCO-HES nanocapsules via copper-free click reaction. These capsules can be taken up by human and murine T cells. Different concentrations of IL-2 on the nanocapsule surface resulted in increased or reduced targeting and proliferation of Treg or effector T cells, respectively, (modified from Frick et al. [69]).

For this purpose, we coupled human IL-2, which interacts with both the human and (less strongly) the murine IL-2 receptors and, thus, can be studied with T cells of both species, to the surface of biodegradable hydroxyethyl starch (HES) nanocapsules. The hydroxy ethyl starch (HES) nanocapsules were synthesized by by an interfacial polymerization reaction in inverse miniemulsion [81]. This approach enables the simultaneous encapsulation of several drugs and reporter molecules in a nanocarrier in a high efficiency. Amino groups on the surface of the nanocapsules can be further functionalized with dibenzocyclooctyne (DBCO) groups for a 1,3-dipolar cycloaddition as copper-free click chemistry. The IL-2 has to be functionalized with azide groups at the $\mathrm{N}$ terminus of the protein. Subsequently, the modified IL-2 can be attached by 1,3-dipolar cycloaddition with the beforehand DBCO-functionalized HES nanocapsules, resulting in defined amounts of surface-bound IL-2 molecules on the nanocapsule surface.

HES-IL-2 nanocapsules exhibited a CD25-mediated uptake by CD25+ $\mathrm{T}$ cells confirmed by blockade with an anti-CD25 antibody basiliximab. Comparing the uptake by naïve CD25- activated effector $\mathrm{CD} 25^{+}$and regulatory CD25 ${ }^{\text {high }}$ human T cells revealed a very low incorporation of HES-IL-2 nanocapsules in naïve, and a moderate to high uptake by activated effector or regulatory $\mathrm{T}$ cells, respectively. Incubation with HES-IL-2 nanocapsules instigated $\mathrm{CD} 4^{+} \mathrm{T}$ cell proliferation upon uptake, confirming the requirement for IL-2/IL2R complex internalization in T cell proliferation (Figure 5) [82].

Reduction of HES-coupled IL-2 levels led to the nanocapsules interacting preferentially with CD25 $5^{\text {high }}$ Treg. Most notably, the capsules were also significantly more strongly absorbed by $\mathrm{CD}^{+} \mathrm{CD}^{2} 5^{+} \mathrm{T}$ cells in human T-cell or peripheral blood mononuclear cell (PBMC)-reconstituted immunodeficient RAG2 ${ }^{-/-} \gamma \mathrm{c}^{-/-}$mice. We did not find any significant differences in the uptake by $\mathrm{B}$ cells, dendritic, and myeloid cells or macrophages, further confirming T cell specific targeting in vivo. Thus, our study clearly showed the development of biocompatible HES-IL-2 nanocapsules exhibiting the ability to target specific $\mathrm{T}$ cell populations with various IL-2 receptor affinities, in particular, regulatory $\mathrm{T}$ cells, through different amounts of surface-coupled IL-2 (Figure 5).

Besides a covalent binding of IL2 to the surface of nanocarriers, we could also successfully show an effective physical adsorption of IL-2 [83]. The IL-2 was adsorbed to HES nanocapsules at pH 6.1-7.5 
and preserved its biological function. It is worth mentioning that the adsorbed IL-2 molecules did not desorb and were not exchanged over time by other proteins from human blood.

\section{Conclusions}

The immune-stimulatory cytokine IL-2 is a growth factor for T cells and natural killer cells. Considerable effort was invested in using IL-2 as therapeutic agent for a variety of diseases, ranging from autoimmune and inflammatory disorders, allograft rejection, to cancer. However, the adverse effects, in particular, IL-2 toxicity leading to the vascular leakage syndrome and the activation of effector and regulatory $\mathrm{T}$ cells depending on the dose of the cytokine, limited the use of IL-2 in the clinic. Therefore, different attempts were made to use the beneficial effects of the IL-2 pathway while limiting unwanted functions. These developments include numerous nanoparticle-based approaches to improve its therapeutic potential by control of IL-2 release, concentration, and targeting of specific $\mathrm{T}$ cell populations (effector/memory vs. regulatory $\mathrm{T}$ cells).

Author Contributions: V.K.R., C.B., K.L. and K.S. wrote parts of the manuscript, V.K.R. additionally designed and generated figures. All authors have read and agreed to the published version of the manuscript.

Funding: This work was supported by the German Research Foundation (DFG): TR156 A4/C5 (KS), SFB1066/B06 (KS), SFB1066/B08 (CB), and SFB1009/B11 (KS), by the German Government as BMBF-related funding (V.R.) and the Center for Thrombosis and Hemostasis Mainz (V.R.).

Conflicts of Interest: The authors declare no conflict of interest.

\section{References}

1. Al-Lawati, H.; Aliabadi, H.M.; Makhmalzadeh, B.S.; Lavasanifar, A. Nanomedicine for immunosuppressive therapy: Achievements in pre-clinical and clinical research. Expert Opin. Drug Deliv. 2018, 15, 397-418. [CrossRef] [PubMed]

2. Pearson, R.M.; Podojil, J.R.; Shea, L.D.; King, N.J.C.; Miller, S.D.; Getts, D.R. Overcoming challenges in treating autoimmuntity: Development of tolerogenic immune-modifying nanoparticles. Nanomedicine Nanotechnol. Biol. Med. 2019, 18, 282-291. [CrossRef] [PubMed]

3. Goldberg, M.S. Improving cancer immunotherapy through nanotechnology. Nat. Rev. Cancer 2019, 19, 587-602. [CrossRef] [PubMed]

4. Irvine, D.J.; Dane, E.L. Enhancing cancer immunotherapy with nanomedicine. Nat. Rev. Immunol. 2020, 20, 321-334. [CrossRef]

5. Rosenberg, S.A.; Yang, J.C.; White, D.E.; Steinberg, S.M. Durability of complete responses in patients with metastatic cancer treated with high-dose interleukin-2: Identification of the antigens mediating response. Ann. Surg. 1998, 228, 307-319. [CrossRef]

6. Rosenberg, S.A. IL-2: The first effective immunotherapy for human cancer. J. Immunol. 2014, 192, 5451-5458. [CrossRef]

7. Klatzmann, D.; Abbas, A.K. The promise of low-dose interleukin-2 therapy for autoimmune and inflammatory diseases. Nat. Rev. Immunol. 2015, 15, 283-294. [CrossRef]

8. Tahvildari, M.; Dana, R. Low-Dose IL-2 Therapy in Transplantation, Autoimmunity, and Inflammatory Diseases. J. Immunol. 2019, 203, 2749-2755. [CrossRef]

9. Arenas-Ramirez, N.; Woytschak, J.; Boyman, O. Interleukin-2: Biology, Design and Application. Trends Immunol. 2015, 36, 763-777. [CrossRef]

10. Morgan, D.A.; Ruscetti, F.W.; Gallo, R. Selective in vitro growth of T lymphocytes from normal human bone marrows. Science 1976, 193, 1007-1008. [CrossRef]

11. Taniguchi, T.; Matsui, H.; Fujita, T.; Takaoka, C.; Kashima, N.; Yoshimoto, R.; Hamuro, J. Structure and expression of a cloned cDNA for human interleukin-2. Nature 1983, 302, 305-310. [CrossRef]

12. Delorme, E.J.; Alexander, P. Treatment of primary fibrosarcoma in the rat with immune lymphocytes. Lancet Lond. Engl. 1964, 2, 117-120. [CrossRef]

13. Mulé, J.J.; Yang, J.; Shu, S.; Rosenberg, S.A. The anti-tumor efficacy of lymphokine-activated killer cells and recombinant interleukin 2 in vivo: Direct correlation between reduction of established metastases and cytolytic activity of lymphokine-activated killer cells. J. Immunol. 1986, 136, 3899-3909. [PubMed] 
14. Lotze, M.T.; Frana, L.W.; Sharrow, S.O.; Robb, R.J.; Rosenberg, S.A. In vivo administration of purified human interleukin 2. I. Half-life and immunologic effects of the Jurkat cell line-derived interleukin 2. J. Immunol. 1985, 134, 157-166.

15. Weiss, G.R.; Margolin, K.A.; Aronson, F.R.; Sznol, M.; Atkins, M.B.; Dutcher, J.P.; Gaynor, E.R.; Boldt, D.H.; Doroshow, J.H.; Bar, M.H. A randomized phase II trial of continuous infusion interleukin-2 or bolus injection interleukin-2 plus lymphokine-activated killer cells for advanced renal cell carcinoma. J. Clin. Oncol. 1992, 10, 275-281. [CrossRef]

16. Krieg, C.; Létourneau, S.; Pantaleo, G.; Boyman, O. Improved IL-2 immunotherapy by selective stimulation of IL-2 receptors on lymphocytes and endothelial cells. Proc. Natl. Acad. Sci. USA 2010, 107, 11906-11911. [CrossRef] [PubMed]

17. Lentsch, A.B.; Miller, F.N.; Edwards, M.J. Mechanisms of leukocyte-mediated tissue injury induced by interleukin-2. Cancer Immunol. Immunother. CII 1999, 47, 243-248. [CrossRef] [PubMed]

18. Yang, J.C.; Sherry, R.M.; Steinberg, S.M.; Topalian, S.L.; Schwartzentruber, D.J.; Hwu, P.; Seipp, C.A.; Rogers-Freezer, L.; Morton, K.E.; White, D.E.; et al. Randomized Study of High - Dose and Low - Dose Inter leukin - 2 in Patients With Metastatic Renal Cancer. J. Clin. Oncol. 2003, 21, 3127-3132. [CrossRef]

19. Granucci, F.; Vizzardelli, C.; Pavelka, N.; Feau, S.; Persico, M.; Virzi, E.; Rescigno, M.; Moro, G.; Ricciardi-Castagnoli, P. Inducible IL-2 production by dendritic cells revealed by global gene expression analysis. Nat. Immunol. 2001, 2, 882-888. [CrossRef]

20. Wojciechowski, W.; Harris, D.P.; Sprague, F.; Mousseau, B.; Makris, M.; Kusser, K.; Honjo, T.; Mohrs, K.; Mohrs, M.; Randall, T.; et al. Cytokine-Producing Effector B Cells Regulate Type 2 Immunity to H. polygyrus. Immunity 2009, 30, 421-433. [CrossRef]

21. Owen, D.L.; Mahmud, S.A.; Vang, K.B.; Kelly, R.M.; Blazar, B.R.; Smith, K.A.; Farrar, M.A. Identification of Cellular Sources of IL-2 Needed for Regulatory T Cell Development and Homeostasis. J. Immunol. 2018, 200, 3926-3933. [CrossRef]

22. Naramura, M.; Hu, R.-J.; Gu, H. Mice with a Fluorescent Marker for Interleukin 2 Gene Activation. Immunity 1998, 9, 209-216. [CrossRef]

23. Serfling, E.; Avots, A.; Neumann, M. The architecture of the interleukin-2 promoter: A reflection of T lymphocyte activation. Biochim. Biophys. Acta 1995, 1263, 181-200. [CrossRef]

24. Kim, H.P.; Imbert, J.; Leonard, W.J. Both integrated and differential regulation of components of the IL-2/IL-2 receptor system. Cytokine Growth Factor Rev. 2006, 17, 349-366. [CrossRef]

25. Leung, D.T.; Morefield, S.; Willerford, D.M. Regulation of lymphoid homeostasis by IL-2 receptor signals in vivo. J. Immunol. 2000, 164, 3527-3534. [CrossRef] [PubMed]

26. Wuest, S.C.; Edwan, J.; Martin, J.F.; Han, S.; Perry, J.S.A.; Cartagena, C.M.; Matsuura, E.; Maric, D.; Waldmann, T.A.; Bielekova, B. A vital role for IL-2 trans-presentation in DC-mediated T cell activation in humans as revealed by daclizumab therapy. Nat. Med. 2011, 17, 604-609. [CrossRef] [PubMed]

27. Sadlack, B.; Merz, H.; Schorle, H.; Schimpl, A.; Feller, A.C.; Horak, I. Ulcerative colitis-like disease in mice with a disrupted interleukin-2 gene. Cell 1993, 75, 253-261. [CrossRef]

28. Suzuki, H.; Kündig, T.M.; Furlonger, C.; Wakeham, A.; Timms, E.; Matsuyama, T.; Schmits, R.; Simard, J.J.; Ohashi, P.S.; Griesser, H. Deregulated T cell activation and autoimmunity in mice lacking interleukin-2 receptor beta. Science 1995, 268, 1472-1476. [CrossRef]

29. Willerford, D.M.; Chen, J.; Ferry, J.A.; Davidson, L.; Ma, A.; Alt, F.W. Interleukin-2 receptor alpha chain regulates the size and content of the peripheral lymphoid compartment. Immunity 1995, 3, 521-530. [CrossRef]

30. Sakaguchi, S.; Sakaguchi, N.; Asano, M.; Itoh, M.; Toda, M. Immunologic self-tolerance maintained by activated $\mathrm{T}$ cells expressing IL-2 receptor alpha-chains (CD25). Breakdown of a single mechanism of self-tolerance causes various autoimmune diseases. J. Immunol. 1995, 155, 1151-1164.

31. Feng, Y.; Arvey, A.; Chinen, T.; van der Veeken, J.; Gasteiger, G.; Rudensky, A.Y. Control of the inheritance of regulatory $\mathrm{T}$ cell identity by a cis element in the Foxp3 locus. Cell 2014, 158, 749-763. [CrossRef] [PubMed]

32. Ohkura, N.; Hamaguchi, M.; Morikawa, H.; Sugimura, K.; Tanaka, A.; Ito, Y.; Osaki, M.; Tanaka, Y.; Yamashita, R.; Nakano, N.; et al. T cell receptor stimulation-induced epigenetic changes and Foxp3 expression are independent and complementary events required for Treg cell development. Immunity 2012, 37, 785-799. [CrossRef] [PubMed] 
33. Malek, T.R.; Yu, A.; Vincek, V.; Scibelli, P.; Kong, L. CD4 regulatory T cells prevent lethal autoimmunity in IL-2Rbeta-deficient mice. Implications for the nonredundant function of IL-2. Immunity 2002, 17, 167-178. [CrossRef]

34. Dooms, H.; Wolslegel, K.; Lin, P.; Abbas, A.K. Interleukin-2 enhances CD4+ T cell memory by promoting the generation of IL-7R alpha-expressing cells. J. Exp. Med. 2007, 204, 547-557. [CrossRef]

35. Teague, R.M.; Tempero, R.M.; Thomas, S.; Murali-Krishna, K.; Nelson, B.H. Proliferation and differentiation of CD8+ T cells in the absence of IL-2/15 receptor beta-chain expression or STAT5 activation. J. Immunol. 2004, 173, 3131-3139. [CrossRef] [PubMed]

36. Granucci, F.; Zanoni, I.; Feau, S.; Ricciardi-Castagnoli, P. Dendritic cell regulation of immune responses: A new role for interleukin 2 at the intersection of innate and adaptive immunity. EMBO J. 2003, 22, 2546-2551. [CrossRef]

37. Malek, T.R. The biology of interleukin-2. Annu. Rev. Immunol. 2008, 26, 453-479. [CrossRef]

38. Saadoun, D.; Rosenzwajg, M.; Joly, F.; Six, A.; Carrat, F.; Thibault, V.; Sene, D.; Cacoub, P.; Klatzmann, D. Regulatory T-cell responses to low-dose interleukin-2 in HCV-induced vasculitis. N. Engl. J. Med. 2011, 365, 2067-2077. [CrossRef]

39. Koreth, J.; Matsuoka, K.; Kim, H.T.; McDonough, S.M.; Bindra, B.; Alyea, E.P.; Armand, P.; Cutler, C.; Ho, V.T.; Treister, N.S.; et al. Interleukin-2 and Regulatory T Cells in Graft-versus-Host Disease. N. Engl. J. Med. 2011, 365, 2055-2066. [CrossRef]

40. Hartemann, A.; Bensimon, G.; Payan, C.A.; Jacqueminet, S.; Bourron, O.; Nicolas, N.; Fonfrede, M.; Rosenzwajg, M.; Bernard, C.; Klatzmann, D. Low-dose interleukin 2 in patients with type 1 diabetes: A phase 1/2 randomised, double-blind, placebo-controlled trial. Lancet Diabetes Endocrinol. 2013, 1, $295-305$. [CrossRef]

41. Rosenzwajg, M.; Churlaud, G.; Mallone, R.; Six, A.; Dérian, N.; Chaara, W.; Lorenzon, R.; Long, S.A.; Buckner, J.H.; Afonso, G.; et al. Low-dose interleukin-2 fosters a dose-dependent regulatory T cell tuned milieu in T1D patients. J. Autoimmun. 2015, 58, 48-58. [CrossRef] [PubMed]

42. Kennedy-Nasser, A.A.; Ku, S.; Castillo-Caro, P.; Hazrat, Y.; Wu, M.-F.; Liu, H.; Melenhorst, J.; Barrett, A.J.; Ito, S.; Foster, A.; et al. Ultra low-dose IL-2 for GVHD prophylaxis after allogeneic hematopoietic stem cell transplantation mediates expansion of regulatory $\mathrm{T}$ cells without diminishing antiviral and antileukemic activity. Clin. Cancer. 2014, 20, 2215-2225. [CrossRef] [PubMed]

43. Woo, E.Y.; Chu, C.S.; Goletz, T.J.; Schlienger, K.; Yeh, H.; Coukos, G.; Rubin, S.C.; Kaiser, L.R.; June, C.H. Regulatory CD4(+)CD25(+) T cells in tumors from patients with early-stage non-small cell lung cancer and late-stage ovarian cancer. Cancer Res. 2001, 61, 4766-4772. [PubMed]

44. Liyanage, U.K.; Moore, T.T.; Joo, H.-G.; Tanaka, Y.; Herrmann, V.; Doherty, G.; Drebin, J.A.; Strasberg, S.M.; Eberlein, T.J.; Goedegebuure, P.S.; et al. Prevalence of regulatory T cells is increased in peripheral blood and tumor microenvironment of patients with pancreas or breast adenocarcinoma. J. Immunol. 2002, 169, 2756-2761. [CrossRef] [PubMed]

45. Wolf, D.; Wolf, A.M.; Rumpold, H.; Fiegl, H.; Zeimet, A.G.; Muller-Holzner, E.; Deibl, M.; Gastl, G.; Gunsilius, E.; Marth, C. The expression of the regulatory T cell-specific forkhead box transcription factor FoxP3 is associated with poor prognosis in ovarian cancer. Clin. Cancer Res. Off. J. Am. Assoc. Cancer Res. 2005, 11, 8326-8331. [CrossRef]

46. Klages, K.; Mayer, C.T.; Lahl, K.; Loddenkemper, C.; Teng, M.W.L.; Ngiow, S.F.; Smyth, M.J.; Hamann, A.; Huehn, J.; Sparwasser, T. Selective depletion of Foxp3+ regulatory T cells improves effective therapeutic vaccination against established melanoma. Cancer Res. 2010, 70, 7788-7799. [CrossRef]

47. Li, X.; Kostareli, E.; Suffner, J.; Garbi, N.; Hämmerling, G.J. Efficient Treg depletion induces T-cell infiltration and rejection of large tumors. Eur. J. Immunol. 2010, 40, 3325-3335. [CrossRef]

48. Carretero, R.; Sektioglu, I.M.; Garbi, N.; Salgado, O.C.; Beckhove, P.; Hämmerling, G.J. Eosinophils orchestrate cancer rejection by normalizing tumor vessels and enhancing infiltration of CD8(+) T cells. Nat. Immunol. 2015, 16, 609-617. [CrossRef]

49. Erdman, S.E.; Poutahidis, T. Cancer inflammation and regulatory T cells. Int. J. Cancer 2010, 127, 768-779. [CrossRef]

50. Ladoire, S.; Martin, F.; Ghiringhelli, F. Prognostic role of FOXP3+ regulatory T cells infiltrating human carcinomas: The paradox of colorectal cancer. Cancer Immunol. Immunother. CII 2011, 60, 909-918. [CrossRef] 
51. Frey, D.M.; Droeser, R.A.; Viehl, C.T.; Zlobec, I.; Lugli, A.; Zingg, U.; Oertli, D.; Kettelhack, C.; Terracciano, L.; Tornillo, L. High frequency of tumor-infiltrating FOXP3(+) regulatory T cells predicts improved survival in mismatch repair-proficient colorectal cancer patients. Int. J. Cancer 2010, 126, 2635-2643. [CrossRef] [PubMed]

52. Droeser, R.; Zlobec, I.; Kilic, E.; Güth, U.; Heberer, M.; Spagnoli, G.; Oertli, D.; Tapia, C. Differential pattern and prognostic significance of CD4+, FOXP3+ and IL-17+ tumor infiltrating lymphocytes in ductal and lobular breast cancers. BMC Cancer 2012, 12, 134. [CrossRef] [PubMed]

53. Boyman, O.; Kovar, M.; Rubinstein, M.P.; Surh, C.D.; Sprent, J. Selective stimulation of T cell subsets with antibody-cytokine immune complexes. Science 2006, 311, 1924-1927. [CrossRef] [PubMed]

54. Létourneau, S.; van Leeuwen, E.M.M.; Krieg, C.; Martin, C.; Pantaleo, G.; Sprent, J.; Surh, C.D.; Boyman, O. IL-2/anti-IL-2 antibody complexes show strong biological activity by avoiding interaction with IL-2 receptor alpha subunit CD25. Proc. Natl. Acad. Sci. USA 2010, 107, 2171-2176. [CrossRef] [PubMed]

55. Arenas-Ramirez, N.; Zou, C.; Popp, S.; Zingg, D.; Brannetti, B.; Wirth, E.; Calzascia, T.; Kovarik, J.; Sommer, L.; Zenke, G.; et al. Improved cancer immunotherapy by a CD25-mimobody conferring selectivity to human interleukin-2. Sci. Transl. Med. 2016, 8, 367ra166. [CrossRef]

56. Margolin, K.; Atkins, M.B.; Dutcher, J.P.; Ernstoff, M.S.; Smith, J.W.; Clark, J.I.; Baar, J.; Sosman, J.; Weber, J.; Lathia, C.; et al. Phase I trial of BAY 50-4798, an interleukin-2-specific agonist in advanced melanoma and renal cancer. Clin. Cancer Res. 2007, 13, 3312-3319. [CrossRef]

57. Pretto, F.; Elia, G.; Castioni, N.; Neri, D. Preclinical evaluation of IL2-based immunocytokines supports their use in combination with dacarbazine, paclitaxel and TNF-based immunotherapy. Cancer Immunol. Immunother. CII 2014, 63, 901-910. [CrossRef]

58. Levin, A.M.; Bates, D.L.; Ring, A.M.; Krieg, C.; Lin, J.T.; Su, L.; Moraga, I.; Raeber, M.E.; Bowman, G.R.; Novick, P.; et al. Exploiting a natural conformational switch to engineer an interleukin-2 "superkine". Nature 2012, 484, 529-533. [CrossRef]

59. Sockolosky, J.T.; Trotta, E.; Parisi, G.; Picton, L.; Su, L.L.; Le, A.C.; Chhabra, A.; Silveria, S.L.; George, B.M.; King, I.C.; et al. Selective targeting of engineered T cells using orthogonal IL-2 cytokine-receptor complexes. Science 2018, 359, 1037-1042. [CrossRef]

60. Ekladious, I.; Colson, Y.L.; Grinstaff, M.W. Polymer-drug conjugate therapeutics: Advances, insights and prospects. Nat. Rev. Drug Discov. 2019, 18, 273-294. [CrossRef]

61. Sharma, M.; Khong, H.; Fa'ak, F.; Bentebibel, S.-E.; Janssen, L.M.E.; Chesson, B.C.; Creasy, C.A.; Forget, M.-A.; Kahn, L.M.S.; Pazdrak, B.; et al. Bempegaldesleukin selectively depletes intratumoral Tregs and potentiates T cell-mediated cancer therapy. Nat. Commun. 2020, 11, 661. [CrossRef]

62. Vazquez-Lombardi, R.; Loetsch, C.; Zinkl, D.; Jackson, J.; Schofield, P.; Deenick, E.K.; King, C.; Phan, T.G.; Webster, K.E.; Sprent, J.; et al. Potent antitumour activity of interleukin-2-Fc fusion proteins requires Fc-mediated depletion of regulatory T-cells. Nat. Commun. 2017, 8. [CrossRef]

63. Lee, J.-Y.; Lee, E.; Hong, S.-W.; Kim, D.; Eunju, O.; Sprent, J.; Im, S.-H.; Lee, Y.J.; Surh, C.D. TCB2, a new anti-human interleukin-2 antibody, facilitates heterodimeric IL-2 receptor signaling and improves anti-tumor immunity. OncoImmunology 2020, 9, 1681869. [CrossRef] [PubMed]

64. Song, G.; Petschauer, J.S.; Madden, A.J.; Zamboni, W.C. Nanoparticles and the mononuclear phagocyte system: Pharmacokinetics and applications for inflammatory diseases. Curr. Rheumatol. Rev. 2014, 10, $22-34$. [CrossRef] [PubMed]

65. Tsoi, K.M.; MacParland, S.A.; Ma, X.-Z.; Spetzler, V.N.; Echeverri, J.; Ouyang, B.; Fadel, S.M.; Sykes, E.A.; Goldaracena, N.; Kaths, J.M.; et al. Mechanism of hard-nanomaterial clearance by the liver. Nat. Mater. 2016, 15, 1212-1221. [CrossRef] [PubMed]

66. Burdick, L.M.; Somani, N.; Somani, A.-K. Type I IFNs and their role in the development of autoimmune diseases. Expert Opin. Drug Saf. 2009, 8, 459-472. [CrossRef]

67. Becker, C.; Bopp, T.; Steinbrink, K. Interferon $\alpha$ interferes with immunological tolerance. OncoImmunology 2013, 2. [CrossRef]

68. Khan, S.; Gerber, D.E. Autoimmunity, checkpoint inhibitor therapy and immune-related adverse events: A review. Semin. Cancer Biol. 2020, 64, 93-101. [CrossRef]

69. Das, P.K.; Wijngaard, R.M.J.G.J.v.d.; Wankowicz-Kalinska, A.; Poole, I.C.L. A symbiotic concept of autoimmunity and tumour immunity: Lessons from vitiligo. Trends Immunol. 2001, 22, 130-136. [CrossRef] 
70. Park, J.; Wrzesinski, S.H.; Stern, E.; Look, M.; Criscione, J.; Ragheb, R.; Jay, S.M.; Demento, S.L.; Agawu, A.; Licona Limon, P.; et al. Combination delivery of TGF- $\beta$ inhibitor and IL-2 by nanoscale liposomal polymeric gels enhances tumour immunotherapy. Nat. Mater. 2012, 11, 895-905. [CrossRef]

71. McHugh, M.D.; Park, J.; Uhrich, R.; Gao, W.; Horwitz, D.A.; Fahmy, T.M. Paracrine co-delivery of TGF- $\beta$ and IL-2 using CD4-targeted nanoparticles for induction and maintenance of regulatory T cells. Biomaterials 2015, 59, 172-181. [CrossRef] [PubMed]

72. Horwitz, D.A.; Bickerton, S.; Koss, M.; Fahmy, T.M.; La Cava, A. Suppression of Murine Lupus by CD4+ and CD8+ Treg Cells Induced by T Cell-Targeted Nanoparticles Loaded With Interleukin-2 and Transforming Growth Factor $\beta$. Arthritis Rheumatol. Hoboken NJ 2019, 71, 632-640. [CrossRef] [PubMed]

73. Votavova, P.; Tomala, J.; Subr, V.; Strohalm, J.; Ulbrich, K.; Rihova, B.; Kovar, M. Novel IL-2-Poly(HPMA)Nanoconjugate Based Immunotherapy. J. Biomed. Nanotechnol. 2015, 11, 1662-1673. [CrossRef] [PubMed]

74. Wu, J.; Tang, C.; Yin, C. Co-delivery of doxorubicin and interleukin-2 via chitosan based nanoparticles for enhanced antitumor efficacy. Acta Biomater. 2017, 47, 81-90. [CrossRef] [PubMed]

75. Fadel, T.R.; Sharp, F.A.; Vudattu, N.; Ragheb, R.; Garyu, J.; Kim, D.; Hong, E.; Li, N.; Haller, G.L.; Pfefferle, L.D.; et al. A carbon nanotube-polymer composite for T-cell therapy. Nat. Nanotechnol. 2014, 9, 639-647. [CrossRef]

76. Liu, M.; Miao, T.; Zhu, H.; Symonds, A.L.J.; Li, L.; Schurich, A.; Maini, M.K.; Zhang, J.; Kennedy, P.T.F.; Li, S.; et al. IL-2-engineered nano-APC effectively activates viral antigen-mediated $\mathrm{T}$ cell responses from chronic hepatitis B virus-infected patients. J. Immunol. 2012, 188, 1534-1543. [CrossRef]

77. Wojta-Stremayr, D.; Neunkirchner, A.; Srinivasan, B.; Trapin, D.; Schmetterer, K.G.; Pickl, W.F. CD8+ T Cell Fate and Function Influenced by Antigen-Specific Virus-Like Nanoparticles Co-Expressing Membrane Tethered IL-2. PloS One 2015, 10, e0126034. [CrossRef]

78. Konigsberg, P.J.; Godtel, R.; Kissel, T.; Richer, L.L. The development of IL-2 conjugated liposomes for therapeutic purposes. Biochim. Biophys. Acta 1998, 1370, 243-251. [CrossRef]

79. Zheng, Y.; Stephan, M.T.; Gai, S.A.; Abraham, W.; Shearer, A.; Irvine, D.J. In vivo targeting of adoptively transferred T-cells with antibody- and cytokine-conjugated liposomes. J. Control. 2013, 172, $426-435$. [CrossRef]

80. Frick, S.U.; Domogalla, M.P.; Baier, G.; Wurm, F.R.; Mailänder, V.; Landfester, K.; Steinbrink, K. Interleukin-2 Functionalized Nanocapsules for T Cell-Based Immunotherapy. ACS Nano 2016, 10, 9216-9226. [CrossRef]

81. Baier, G.; Baumann, D.; Siebert, J.M.; Musyanovych, A.; Mailänder, V.; Landfester, K. Suppressing unspecific cell uptake for targeted delivery using hydroxyethyl starch nanocapsules. Biomacromolecules 2012, 13, 2704-2715. [CrossRef] [PubMed]

82. Duprez, V.; Ferrer, M.; Cornet, V.; Olive, D.; Dautry-Varsat, A. Modulation of interleukin 2 internalization and interleukin 2-dependent cell growth by antireceptor antibodies. J. Biol. Chem. 1991, 266, 1497-1501. [PubMed]

83. Tonigold, M.; Simon, J.; Estupiñán, D.; Kokkinopoulou, M.; Reinholz, J.; Kintzel, U.; Kaltbeitzel, A.; Renz, P.; Domogalla, M.P.; Steinbrink, K.; et al. Pre-adsorption of antibodies enables targeting of nanocarriers despite a biomolecular corona. Nat. Nanotechnol. 2018, 13, 862-869. [CrossRef] [PubMed]

(C) 2020 by the authors. Licensee MDPI, Basel, Switzerland. This article is an open access article distributed under the terms and conditions of the Creative Commons Attribution (CC BY) license (http://creativecommons.org/licenses/by/4.0/). 